passing vinden. Amerikaansche en Engelsche opvattingen (en naar we hopen ook die van Fransche en Scandinavische denkers) zullen grooter vat op onze praktijk krijgen dan zij thans reeds hadden.

Dit alles houdt echter in, dat de toegepaste economie - en de bedrijfseconomie in het bijzonder - een belangrijke rol, belangrijker nog dan voorheen, zal spelen in de samenleving.

In die ontwikkeling zal men het zonder de moderne bedrijfshuishoudkundige grondslagen niet kunnen stellen; ook zal de moderne „budgetcontrole" in ruimere mate worden toegepast. Daarnevens zal de verplichte controle door - aan reglementen van arbeid, orde en tucht gebonden accountants een vereischte zijn. Naast de doorvoering van onze moderne bedrijfseconomische methoden zal dus een wettelijke regeling van het accountantsberoep eisch zijn. Dat zal dus ook een regeling moeten zijn, die bekrachtigt, wat door den strijd voor goede beroepsuitoefening bereikt werd.

\title{
HET BUITENGEWOON NAVORDERINGSBESLUIT
}

door $A$. Nierhoff

Het is van algemeene bekendheid, dat velen in de jaren van de bezetting het met hunne fiscale verplichtingen niet zoo nauw hebben genomen. De aanleiding hiertoe was uiteenloopend. Goederen, die buiten het distributie-apparaat in den handel werden gebracht, konden in de boekhouding niet worden verantwoord. De winsten, met deze goederen behaald, kwamen in de winstrekening niet tot uitdrukking. De ,zwarte kas" werd in de balans niet opgenomen. Overtreding van de voorschriften voor de prijsbeheersching leidde eveneens tot het niet verantwoorden van winst en vermogen. Vordering van goederen door den bezetter had vaak ten gevolge, dat een gedeelte der aanwezige goederen ,ter zijde" werd gezet en buiten de administratie werd gehouden. Betrof het artikelen, waarvoor een hoeveelheidscontrôle moeilijk kon worden uitgeoefend, dan kon men des te eerder tot een dergelijken maatregel over gaan. Al deze gevallen leidden tot het verzwijgen van winst, vermogen en omzetten bij de belastingaangiften. Ook waren er die te lage aangifte deden onder het motief, dat de belastingpenningen toch aan den bezetter ten goede kwamen. De bona-fide belastingplichtigen hadden daarbij het voornemen later, na de bevrijding, vrijwillig verbeterde aangifte te doen, om dan te kunnen bijdragen tot de verbetering van 's lands financiën.

Het Buitengewoon Navorderingsbesluit, dat men ook Zuiveringsbesluit zou kunnen noemen, biedt gelegenheid met verzwegen inkomen en vermogen voor den dag te komen. Men kan door het doen van een navorderingsaangifte voor in het verleden te weinig betaalde belastingen worden nagevorderd zonder dat de wettelijke verhoogingen bij navordering worden toegepast of strafvervolging wegens belastingontduiking wordt ingesteld. De te weinig geheven belasting wordt bij navordering alleen met $10 \%$ verhoogd, zijnde een vergoeding voor renteverlies en kosten. Het is de bedoeling in het algemeen te volstaan met belastingheffing over de jaren, waarover volgens de wettelijke bepalingen navordering nog mogelijk is. De navordering heeft volgens art. 1 van het Besluit betrekking op belastingjaren aangevangen met of na 1 Januari 1941. 
Voor 's Rijks schatkist zijn van het meeste belang: inkomsten-, winst-, vennootschaps- en ondernemingsbelasting. Daarnaast noemt art. 1 ook: commissarissenbelasting, geblokkeerde-markenbelasting, herkapitalisatiebelasting, superdividendbelasting, vereveningsheffing, vermogensbelastingen, waardevermeerderingsbelasting, dividendbelasting, omzetbelasting en invoerbelasting (verschuldigd ingevolge Besluit op de Omzetbelasting 1940). Voor de winstbelasting kan bovendien volgens art., 1 worden nagevorderd voor het eenige of laatste jaar, geëindigd in 1940 en indien iI Januari 1940 tot een vroeger boekjaar behoort, ook voor dit vroegere boekjaar.

Navordering kan plaats hebben tot en met 31 December 1950 , ook dan als de wettelijke navorderingstermijn is verstreken.

Het buitengewoon aangiftebiljet voor natuutlijke personen stelt belastingplichtige in de gelegenheid o.m. verbeterde aangifte te doen voor het inkomen in de jaren 1941, 1942 en 1943 en van het vermogen voor de belastingjaren $1941 \mathrm{t} / \mathrm{m} 1944$. Het biljet is tevens dienstbaar gemaakt voor het doen van een aangifte van het inkomen in 1944 en het tijdvak 1 Januari tot 1 September 1945, alsmede van het zuiver vermogen op 1 September 1945. Door vermogensvergelijking zal men kunnen vaststellen of het totaal inkomen voor het tijdvak 1941 - 1 September 1945 in overeenstemming is met het vroeger aangegeven vermogen voor het belastingjaar $1940 / 41$ en het thans aangegeven vermogen per 1 September 1945. Het verschil in vermogen zal nog vermeerderd moeten worden met het verteerde inkomen.

Voor natuurlijke personen wordt volgens art. 3, tenzij het tegendeel overtuigend wordt aangetoond, aangenomen dat:

a. op 1 Januari 1941 geen ander vermogen aanwezig was, dan op 31

December 1942 bij de Administratie van de belastingen bekend was;

$b$. veranderingen in grootte en samenstelling van het vermogen na 1 Januari 1941, uitsluitend in 1942 hebben plaats gehad;

c. toeneming van vermogen is ontstaan door besparing van inkomen;

d. zuiver inkomen, waarover moet worden nagevorderd, winst is van een jaar, waarin een niet agrarisch bedrijf wordt uitgeoefend.

Punt $d$. heeft beteekenis voor de ondernemingsbelasting. In het daar genoemde geval wordt behalve inkomsten- ook ondernemingsbelasting nagevorderd.

Op het buitengewoon aangiftebiljet voor de lichamen wordt o.m. opgave verzocht van de in werkelijkheid genoten winst over de boekjaren $1940(1939 / 40)$ tot en met $1943(1943 / 44)$ en van het bedrijfsvermogen bij het begin van de boekjaren 1941 (i1940/41) tot en met 1944 (1943/ 44), alsmede van de geschatte winst over het loopende boekjaar tot 1 September 1945.

Voor de heffing van de winst-, de vennootschaps-, de vermogensen de ondernemingsbelasting zal volgens art. 4, 1e lid, van het Besluit aan het licht gekomen vermogen als winst worden beschouwd van het jaar, waartoe 1 Januari 1942 behoort, voor zoover niet wordt aangetoond, tot welk ander jaar zij moet worden gerekend. Verder is nog bij art. $4,2 \mathrm{e}$ lid, bepaald, dat aangenomen wordt, dat de waardeeringen bij het begin van het jaar, waartoe 1 Januari 1940 behoort, juist zijn geweest; de mogelijkheid is echter wel opengelaten hierop terug te komen.

Eene belangrijke bepaling, tot heden in ons belastingstelsel onbekend, bevat het Besluit ten aanzien van het verstrekken van inlichtingen. In-

m a b blz. 12 
gevolge art. 10 is een ieder verplicht aan iederen inspecteur der belastingen, aan iederen inspecteur der accijnzen en aan iederen ambtenaar van 's Rijks belastingdienst, belast met onderzoek van boeken en bescheiden, de gegevens te verstrekken noodig voor de uitvoering van het Besluit of voor de heffing van eenige Rijksbelasting. De gegevens dienen hetzij schriftelijk, hetzij mondeling te worden verstrekt, hetzij door het verleenen van inzage van boeken en bescheiden, ter keuze van dengene, die de gegevens vordert. Aangenomen wordt, dat degene, wien inzage van boeken en bescheiden wordt gevraagd, deze in zijn bezit heeft gehad, tenzij het tegendeel aannemelijk wordt gemaakt. Niemand kan zich er op beroepen, dat hij tot geheimhouding verplicht is, ook niet wanneer deze bij eene wettelijke bepaling is opgelegd. Notarissen, advocaten en accountants moeten dus ook aan de verplichting voldoen.

Daar de verplichting tot het verstrekken van gegevens en inzage verleenen van boeken en bescheiden zonder eenige beperking aan een ieder wordt opgelegd, vallen ook bankinstellingen er onder. De opheffing van het bankgeheim zal voor de belastingheffing van verstrekkende beteekenis blijken te zijn.

Aan de aanslagregelende en controleerende ambtenaren zal de nieuwe bepaling veel steun verleenen bij het verrichten van hun arbeid. De mogelijkheid van het opvragen van gegevens en van inzage nemen van boeken en bescheiden bij derden zal het doen van juiste belastingaangiften zeer bevorderen.

Ten slotte dient nog vermeld te worden de inventarisplicht, voorgeschreven in art. 11 van het Besluit. Aan een ieder kan door den Minister van Financiën de verplichting worden opgelegd, naar den toestand op één of twee door den Minister te bepalen tijdstippen, een inventaris op te maken van alle betaalmiddelen en roerende goederen, die hij van anderen onder zich heeft. Voorts kan een ieder door den Minister van Financiën verplicht worden een inventaris op te maken van zijn roerend vermogen en van zijne schulden. Door deze bepalingen wordt mogelijk gemaakt, dat inkomen van vroegere jaren, in roerende goederen belegd. aan het licht wordt gebracht.

In de naaste toekomst zal blijken, dat het Buitengewoon Navorderingsbesluit belangrijke inkomsten voor de schatkist zal opleveren. Vooral de bepaling betreffende het verstrekken van gegevens door derden zal daartoe veel bijdragen. De Minister van Financiën heeft verschillende maatregelen laten volgen, die de belastingadministratie belangrijke contrôlemiddelen bij het verrichten van haar taak zullen verschaffen. Als zoodanig kunnen worden vermeld:

\section{Beschikking Fiscale Recherche.}

Hierbij wordt aan in de Beschikking aangegeven personen en lichamen de verplichting opgelegd gegevens te verschaffen betreffende den creditstand per 30 September 1945. der gevoerde rekeningen en van aflossingen van geldleeningen of andere vorderingen in het tijdvak 30 April 19401 October 11945 . Voorts moet door verzekeraars en agenten opgave verstrekt worden van nader aangegeven verzekeringen tegen brand van inboedels. Ten slotte zijn levensverzekeringsbedrijven verplicht de in de beschikking vermelde gegevens te verstrekken. 


\section{Beschikking safe-onderzoek.}

Het doel van dezen maatregel is het inzage nemen door den Inspecteur van den inhoud van safe of trommel bij derden, die safes verhuren of trommels in bewaring nemen. Ook hierdoor wordt de belastingadministratie gegevens verstrekt omtrent vermogen, dat eventueel verzwegen wordt.

\section{Besluit uitbreiding bevoegdheden belastingambtenaren.}

Bij dit Besluit heeft de Inspecteur de bevoegdheid verkregen zich toegang te verschaffen tot alle plaatsen, waarvan hij het ernstig vermoeden heeft, dat zich aldaar voorwerpen of gegevens bevinden, die voor het vaststellen van belastingaanslagen of het leggen van conservatoir beslag van belang zijn.

Ten slotte moet nog de aanstaande effectenregistratie worden vermeld, die een volledig overzicht zal geven van het effectenbezit van alle personen en lichamen.

\section{DE OVERHEIDSADMINISTRATIE EN DE ACCOUNTANT}

\section{door J. E. Spinosa Cattela}

In de Maart en Aprilnummers van The Journal of Accountancy komen een tweetal lezenswaardige artikelen voor met betrekking tot de verhouding van den accountant tot de overheidsadministratie.

In het artikel .Developments in Auditing" (April 1945) van Paul Grady worden verschillende punten behandeld, die naar schrijvers mening voor de toekomstige ontwikkeling van het accountantsberoep van belang zijn, te weten: training van het personeel en van den jongen accountant, vermijding van de seizoenspieken in de accountantsarbeid, verbreding van de adviserende en controlerende functie, en ten vierde de taak van den accountant bij het streven naar een doeltreffend verantwoordingssysteem van de overheid. De behandeling van de eerste drie dezer desiderata opent voor den Nederlandschen accountant geen nieuwe gezichtspunten, doch het komt mij voor dat een beschouwing van het laatste punt nuttig kan zijn.

De schrijver wijst erop hoe de hoge eisen welke aan de particulierezowel als aan de overheidsadministratie gedurende de oorlogstijd gesteld worden (o.a. in verband met het groot aantal regeringsopdrachten, de lend-lease administratie e.d.) ertoe geleid hebben dat meer dan te voren de accountant adviserend en controlerend ten bate van de overheid optrad. Ook in de na-oorlogse tijd zal de hulp van den particulieren accountant onontbeerlijk zijn. (In dit verband zij er op gewezen dat reeds geruime tijd de vaklitteratuur allerlei beschouwingen bevat over ,termination of war contracts"). Een erkenning van de sociale taak en verantwoordelijkheid van den accountant brengt mede dat hij zich dient voor te ber reiden op nauwe samenwerking met de overheidsinstanties, teneinde ertoe te geraken, dat ,in our largest business, the government", behalve aan de eisen, die de begrotingstechniek stelt, ook aan de eisen van meer dynamische aard, die zich in de toekomst bij de overheid zullen doen gelden, kan worden voldaan. 